https://doi.org/10.18485/iipe_60nam.2021.ch7

\title{
CHINESE POLICIES TOWARDS THE NON-ALIGNED MOVEMENT
}

\author{
Xinyao LIU \\ Hongwei FAN ${ }^{1}$
}

\begin{abstract}
China has always been supportive and sympathetic to the NonAligned Movement (NAM) and its main initiatives over six decades. Very little scholarly attention was accepted by the history of China-NAM relations and the understanding of Chinese foreign policy towards the NAM since its inception in 1961 remains incomplete. Based on People's Daily (Renmin ribao), China's most influential official newspaper of the Central Committee of the Chinese Communist Party (CCP), this article tends to fill the gap between scholarly works on the PRC's diplomatic history. By tracing the dynamics of China and NAM interactions under each demarcated period, this article aims to generate a brief review of the evolution of Chinese policies towards the NAM from 1961 to 2021.
\end{abstract}

Key words: Non-Aligned Movement; NAM Summit; Cold War; Third World.

\section{Introduction}

Before the formal launch of the Non-Aligned Movement (NAM) in 1961, China worked closely with the troika of the NAM and contributed to the Five Principle of Peaceful Co-existence, which illuminated the setting of the NAM's principles of independence, self-determination, and non-grouping. As the largest forum for developing countries, the NAM has attracted China's attention since its inception. China identified the potential of the

\footnotetext{
${ }^{1}$ Researcher and Professor, Research School of Southeast Asian Studies, Xiamen University, China.

E-mail: fhw@xmu.edu.cn
} 
NAM for furthering its foreign policy goals. Although China had not become a NAM observer until September 1991, Beijing sent congratulatory telegrams to each NAM Summit Conference in support of the NAM's proactive role in promoting the fight against colonialism, neocolonialism, imperialism, hegemony and ensuring national independence and sovereignty of the Southern hemisphere in the Cold War. China and the NAM relations reached their heyday in the first decade since the end of the Cold War, during which China was officially granted as an observer and the direct interactions between the two sides mushroomed. China has always affirmed the important role of the NAM in representing developing countries in international affairs, but the NAM has been progressively moving out of China's attention from 2000 onwards.

\section{The stranglehold of American imperialists and India (1961-1969)}

The period of the 1960s witnessed the radicalisation and revolutionisation of China's foreign policy. After Mao Zedong came back from the visit to the Soviet Union in 1957, he criticised the Soviet Communist Party's general foreign policy line of peaceful co-existence. For proletarian internationalism, Mao believed the general foreign policy line of socialist countries should involve more contents, including supporting the world revolution, anticolonialist, and anti-imperialist movement (Wu, 1999, p. 152). In the Lushan Meeting of 1959, Zhang Wentian, the Vice Minister of Foreign Affairs was classified as a member of "Peng Dehuai Anti-Party Group" and a "Right opportunist". After the meeting, the "Anti-Rightist Movement" was launched again. As a result, in September, Zhang's proposal of a peaceful coexistence foreign policy line labelled as the rightist opportunist line was further criticised at the National Foreign Affairs Conference. In October, the Foreign Minister held a special meeting to continue criticising Zhang's peaceful co-existence foreign policy thinking (Zhang, 2000, pp. 1156-1157). Zhang's prominent position in the CCP and Ministry of Foreign Affairs was associated with the criticism over his peaceful co-existence foreign policy thinking during those two meetings, resulting in the interruption of Five Principles of Peaceful Co-existence that defined China's pragmatic and moderate foreign policy line in 1954 (Niu, 2019, p. 320). In 1962, Wang Jiaxiang, the Chief of the CCP International Bureau was fiercely attacked by Mao because Wang advised that China should endeavour to search for a stable relationship with major powers (Niu, 2019, p. 348). In the 1960s, Beijing began to pursue less pragmatic, calculated but more ideological or radical foreign policy. The general radicalisation and revolutionisation of China's 
foreign policies could be seen from China's policy towards the NAM. China's perception of post-colonial Asian-Afro-Latin American developing countries, where the NAM members came from, had its origins in Mao's philosophy of the "intermediate zone". In the 1960s, the concept of the "intermediate zone", was gradually evolved into a line of strategic thinking that aimed to unite both intermediate zones to form an anti-imperialist international united front. $^{2}$ As the Sino-Soviet split and the Sino-Indian dispute deteriorated, Beijing began to shift its attention to the post-colonial Afro-Asian-Latin American developing countries that could be potential new allies in an international anti-imperialist united front against the U.S. and India. In the 1960s, China demonstrated its rhetorical support for the newly emerged international organisation - NAM by means of congratulatory telegrams, through which China defined the nature of the NAM as anti-colonialism and anti-imperialism. All the congratulatory telegrams were sent by Premier Zhou Enlai, in which he advocated the NAM's further contributions to AsianAfro-Latin American people and their national independence and their struggle of anti-(neo-) colonialism and anti-imperialism (People's Daily, 1961a; People's Daily, 1964a). China thus praised the countries which shared the same clear-cut anti-(neo-) colonialism and anti-imperialism viewpoints, such as Indonesia and Egypt, and criticised India because of its apathetic to anti-colonialism and anti-imperialism. Nehru asserted that the conference should not condemn any country and defined the NAM as a mediator of two superpowers. Nehru believed not colonialism and imperialism, but war and peace should be the primary concerns for the NAM member states (People's Daily, 1961b). What made China most dissatisfied was that neither India nor Yugoslavia mentioned American imperialism (People's Daily, 1961b). On 9 September 1961, the Vice Prime Minister Chen Yi rebutted that "The people of Asia, Africa and Latin America have deeply realised that without independence and freedom, there can be no talk of defending peace and without breaking the chains of imperialism and colonialism, there can be any talk of coexistence." (People's Daily, 1961c). He criticised that "those who attempt to shift the important goals of the conference cannot win people's support and are therefore isolated." (People's Daily, 1961c). Between 1961 and 1966, China attempted to isolate Yugoslavia and India in the NAM,

${ }^{2}$ In 1963, Mao believed there were two intermediate zones, the first zone included Asia, Africa and Latin America, and the second zone represented Europe, Canada, Japan and Oceania. The first zone constituted the main force to overwhelm American imperialists. The countries in the second zone, such as Britain, France and Japan could be the indirect allies of people to counter American imperialists. 
especially India, because Beijing perceived India abandoned non-alignment policy and allied with the U.S. to fight with China over a border dispute. In addition, the Sino-Indian border war attracted the attention of some NAM members in 1962. They tried to mediate the conflict to ease Sino-Indian border tensions. Ceylonese Prime Minister Sirimavo Bandaranaike initiated the Colombo Conference to resolve the crisis. Burma, Cambodia, Indonesia, Egypt, and Ghana participated in it. On the first day of the Colombo Conference, Zhou Enlai sent a telegram to the leaders at the conference and claimed that the Sino-Indian border dispute should and could be resolved through peaceful negotiations between China and India and hoped that the conference could make positive contributions to promoting the resumption of negotiations between China and India (People's Daily, 1962a). However, the final mediation plan initiated by the Colombo Conference failed because Beijing regarded it as tilted towards India (Lüthi, 2016, pp. 96-97). In an address to the second NAM Summit Conference in 1964, Nehru's successor Lal Bahadur Shastri stated that "although we accepted all proposals proposed by the Colombo Conference, we have not received a positive response from China" (People's Daily, 1964a). In response, China asserted that India "imposed various preconditions to prevent China and India from holding direct negotiations on the border issue" (People's Daily, 1964b). Moreover, Beijing also excerpted the numerous pro-Communist comments from the NAM member countries and created an atmosphere that China garnered more supports than India among the NAM countries over the SinoIndian border conflict. The editorial of People's Daily on 23 December 1962 listed the military cooperation between India and the U.S. after the SinoIndian border ceasefire and stressed that it started earlier (People's Daily, 1962b). China attempted to demonstrate that India had given up its neutral stance, and it was not a representative of "emerging Asian and African forces" (People's Daily, 1962c). China contrasted itself with India to highlight its unflagging resistance to imperialism and depicted the latter as a stooge of American imperialism. In the 1960s, Beijing built support for the restoration of the lawful seat of the PRC in the United Nations (UN) from the NAM member states. Beijing's appeals were included in the Belgrade Declaration of the Heads of State or Government of Non-Aligned Countries. During the First and the Second NAM Summit Conference, the NAM member states, including Burma, Indonesia, Nepal, Cambodia, Ceylon, and Ghana, unanimously advocated that the UN should accept the PRC as the only legitimate representative of China in the UN. From 1967 to 1969, the NAM was hardly mentioned in the People's Daily primarily because of China's domestic dramatic upheaval as well as no conference held by the NAM 
during this period. Although the participants in the second Cairo Conference had not arranged to hold a further non-aligned Conference, from 1964 onwards, influential personalities such as Tito, Nasser and Indira Gandhi vigorously attempted to bring about further non-aligned Conferences. Nonetheless, the majority of non-aligned governments reckoned that it was no sense in holding additional meetings because they had reached their most important common foreign policy goals - eliminating colonialism and gaining independence, or were seemingly well on their way to doing so (Dinkel, 2016, p. 110). The chaotic Cultural Revolution broke out in 1966, and Beijing pursued a more radical foreign policy. As a result, China became one of the world's most isolated countries at the time. Between 1966 and 1969, China failed to establish diplomatic relations with new countries. Nearly 30 of the 53 countries that established diplomatic relations or half-diplomatic relations with China successively went into diplomatic disputes with China. Five countries, including Indonesia, had terminated their diplomatic relations with China (Yang, 2007, p. 5). Under such circumstances, the NAM was not in China's interests.

\section{Opposing two hegemonies and anti-Soviet hegemony in particular (1970-1979)}

In the 1970s, China's radicalism was de-escalated, and Beijing shifted to a more moderate course. It improved its relations with numerous developing countries that had previously regarded it with suspicion. In particular, reintegrating into the international community, Beijing replaced Taiwan as China's representative to the UN in 1971. Meanwhile, Mao Zedong set forth his strategic thinking of the division of the Three Worlds in 1974 under the context of the Sino-Soviet conflict and Sino-American rapprochement. According to the theory, the First World including America and the Soviet Union were the biggest oppressors and exploiters. The Second World countries were dominated by two hegemons to varying degrees and some of them still colonised the Third World countries. Although the Third World was oppressed and exploited, they were the main force of anti-colonialism and anti-imperialism. Officially, Chinese statements called for a struggle against the hegemony of the First World, but largely against the Soviet Union, which was perceived as the biggest threat by Beijing. As the largest Third World forum in the mid-1970s, China tried to seek support from the NAM member states to form an international united front against the Soviet Union. As more and more Asian-Afro-Latin American countries gained independence and joined the NAM in the 1970s, the main task for the NAM 
progressively evolved into maintaining their national independence and sovereignty and preventing the hegemonic powers' intervention. Furthermore, the NAM demanded a new international economic order. Dinkel (2016, p. 117) argues that "the demands the NAM voiced together with G77, calling for the establishment of a new global order of both the economy and the information media, culminated in the North-South conflict that profoundly characterised the decade." Some Chinese scholars hold the view that China's focus towards the NAM shifted to the economic sphere in the 1970s (Gao, Cheng and Wei, 2018, p. 15). Although China also noticed the NAM's growing focus on economic issues and support its appeal of restructuring the global order of economy in the 1970s, in general, political and ideological issues remained China's NAM policy priorities. One of the cases in point was Cambodia. On 20 May 1970, Mao Zedong issued a statement of "People of the World, united and defeat the U.S. aggressors and all their running dogs", which fiercely condemned American involvement in Cambodia, praised Sihanouk's spirit of fighting American imperialists, and supported the establishment of Sihanouk-led Coalition Government of Democratic Kampuchea (zhonggong zhongyang wenxian yanjiushi, 1994, p. 584). On 21 May, the Chinese government held a mass rally of half million people in Beijing to support the people of the world in their struggle against U.S. imperialism and Mao's statement issued the day before (zhonggong zhongyang wenxian yanjiushi, 1998, p. 367-368). Sihanouk and his wife also attended the rally. In addition to domestic support measures in favour of Sihanouk, Beijing sought to use the NAM for debating American intervention in Cambodia's internal affairs. The Royal Government of the National Union of Cambodia (RGNUC) headed by Sihanouk seized every opportunity to create and reinforce its legitimacy among the NAM member states and China also helped the RGNUC to attend a series of NAM Conferences. In August 1972, during the Conference of Foreign Ministers of Non-Aligned Countries held in Georgetown, the Chinese leaders instructed the diplomats of the Chinese Embassy in Guyana to "actively cooperate with [RGNUC] in the struggle of destroying the conspiracy of the Lol Nol clique and restoring the seat of the legitimate Cambodian government led by Prince Sihanouk in the NAM" (Xu, 2007, p. 210-211). As a result, the RGUNC was recognised as the sole legitimate authority within Cambodia at the Georgetown Conference. People's Daily provided a lengthy report to the Conference and its resolutions which proclaimed that the Indochina and Cambodian representative issues were "not only a victory of the Cambodian peoples, but also a common victory in defence of justice of the people of the world." (People's Daily, 1972). In the 1970s, both China and the NAM 
emphasised the anti-imperialist position. Comparatively speaking, the latter began to focus its agenda on opposing hegemony. Also, economic issues had gradually taken over from anti-colonialism as the major concern for the NAM states during this period. In the congratulatory telegrams to the NAM Summit Conferences in 1970 and 1973, Zhou Enlai encouraged the NAM to promote the unity and struggle of the people of Asia, Africa and Latin America against imperialism and hegemony (People's Daily, 1970; People's Daily, 1973). In the 4th NAM Summit Conference, the wording, "against hegemony" and rejection of "any form of subordination or dependence and any interference or pressure" were enshrined in the Political Declaration of the Conference for the first time (Documents of the Fourth Conference of Heads of State or Government of Non-Aligned Countries, 1973, p. 9). However, due to the Sino-US rapprochement in the early 1970s, Beijing mitigated criticism of the U.S. while Chinese verbal attacks on the Soviet Union and Vietnam increased mainly because of the growing division and worsening relations between the Soviet Union and China, and the Vietnamese invasion of Cambodia. "The Soviets supported the Vietnamese invasion primarily through grants of economic and military aid, including the airlift and sealift of Soviet materiel, shuttling of Vietnamese troops and equipment to the Cambodian theatre, and the dispatch of Soviet military advisers to Vietnam to train air force personnel." (Stoecker, 1989, p.7) The Vietnamese invasion and the Soviet-Vietnam alliance posed a threat to Chinese security and exacerbated the regional situation. The NAM's tune of counter-hegemony posed challenges for the Soviet hegemonic expansion in the Third World. Since the 5th Summit Conference in August 1976, on the one hand, the Soviet Union preached that it was a natural ally of the NAM, trying to persuade the NAM to oppose imperialism rather than hegemonism. On the other hand, the Soviet Union sought to reinforce its dominance within the NAM. Although Beijing condemned the Soviet influence in the NAM, the host country Cuba was particularly assertive in defending Soviet interests within the NAM during the 6th Summit Conference in Havana in 1979. Under the leadership of Fidel Castro, the Summit discussed the concept of an anti-imperialist alliance with the Soviet Union and tried to prevent the NAM from opposing hegemony (People's Daily, 1979a). Cuba attempted to move the NAM closer to the Soviet camp. The Chinese Government attached great importance to this Conference and promptly demonstrated once again its support for maintaining the NAM unity. Premier Hua Guofeng sent a message of congratulations on its opening. Hua claimed that the Chinese government strongly believed that "the vast number of NAM countries can rely on their solidarity (...), and eliminate the interference of imperialism and 
hegemonism" (People's Daily, 1979b). On the surface, the final Political Declaration of Havana conference reaffirmed the fundamental goals and purposes of the Movement which has guided it since its inception in 1961, including "independence of non-aligned countries from great-Power or bloc rivalries", "non-interference and non-intervention in internal and external affairs" and "elimination of all forms of hegemony" (Documents of the Sixth Conference of Heads of State or Government of Non-Aligned Countries, 1979 , p. 11-12). In the 1970s, it appeared that the non-aligned movement was tilting towards the Soviet Union.

\section{Less politics, more economy: \\ A non-aligned China and the NAM (1980-1990)}

In the late 1970s and early 1980s, China's economic pragmatism began to temper ideology which shaped and influenced foreign policy-making. At the political level, China continued to support the NAM's struggle against hegemony in the 1980s. According to Deng Xiaoping, China faced three major tasks in the 1980s. They were to oppose hegemonism and safeguard world peace, to strive for China's unification and particularly for the return of Taiwan to the motherland; step up socialist economic modernisation. (zhonggong zhongyang wenxian bianji weiyuanhui, 1983, p. 239). In the 1980s, Beijing continued to push the NAM to make further contributions to the struggle against hegemony (People's Daily, 1983a; People's Daily, 1986a). Furthermore, China recalibrated its foreign policy and established an "independent and self-reliant foreign policy of peace" without leaning to any side in the early 1980s. Consequently, Beijing believed that the friendship and cooperation between the two sides would be undoubtedly deepened because both shared a common value orientation (People's Daily, 1986b; People's Daily, 1989a). "By the mid-1970s, economic development among the non-aligned had replaced many of their original goals." (Lüthi, 2016 b, p.100) However, Beijing did not start to focus more on the NAM's efforts in the economic sphere until the 1980s, supporting the NAM's positive role in building a fair and equitable international economic order and promoting North-South and South-South cooperation. In the opening address at the 12th National Congress of the CCP in 1982, Deng Xiaoping articulated that economic construction was at the core of three tasks, and it was the basis for the solution of our external and internal problems. (zhonggong zhongyang wenxian bianji weiyuanhui, 1993, p. 3). As China shifted the focus to economic construction, its foreign policy was designed to serve its economic transformation and development. In the 
spring of 1985, Deng Xiaoping concluded that "the two great issues confronting the world today, issues of global strategic significance are: first, peace, and second, economic development. The first involves East-West relations, while the second involves North-South relations." (zhonggong zhongyang wenxian bianji weiyuanhui, 1993, p.105). Premier Zhao Ziyang in June further explained that "the essence of the North-South problem is the widening economic gap between the developing countries and the developed countries. The most important reason for this situation is the existence of the unfair and unreasonable international economic order" (People's Daily, 1985). The NAM first put forward the slogan of establishing a new international economic order in 1964, and at the 4th NAM Summit Conference in 1973 formally adopted it as the NAM's programme of action and formulated a series of strategies to achieve this goal since then. Although China supported this advocacy in the 1970s, it was not until the 1980s that replacing the existing international economic order became an aspiration shared by both NAM and China. By the early 1980s, Chinese foreign policy was increasingly shaped by economic interests. Beijing's political discourse of development and cooperation defined the basic tones of Chinese policies towards the NAM and the other developing countries. In the summer of 1983, Premier Zhao Ziyang announced that "China will take South-South cooperation as the foothold for its foreign economic cooperation" (People's Daily, 1983b). In 1984, Deng Xiaoping claimed that China would always belong to the Third World, which was the foundation of China's foreign policy. China shared a common destiny with all the Third World countries and supported the North-South dialogue. Meanwhile, the cooperation among the Third World countries, South-South cooperation should be stepped up. (zhonggong zhongyang wenxian bianjishi, 1993, p. 56). At the opening ceremony of the 9th NAM Summit Conference, the chairman of the Conference, Janez Drnovsek, stated that the most important issue of non-aligned countries was the issue of development (People's Daily, 1989a). On 10 September 1989, Beijing emphasised again that the NAM placed special emphasis on strengthening South-South cooperation and advocated the development of unity and long-term cooperation within nonaligned countries. China supported this advocacy (People's Daily, 1989b).

\section{From an outsider to an observer (1991-1999)}

During the Cold War, Beijing's overriding challenge was to ensure a relatively weak China's security in the face of pressing threats from the Soviet Union and the U.S. As a result, the priority was clearly to address core survival 
concerns and the imperatives for Chinese diplomacy were correspondingly straightforward. (Goldstein, 2001, pp. 835-836) The end of the Cold War lifted the curtain on new China's foreign relations. In the last decade of the 20th century, China expanded the breadth and depth of its foreign relations, particularly regarding Southeast Asian countries. In 1991, for the first time, normalized relations existed between China and all ASEAN countries, and China was invited to attend an ASEAN summit. In 1996 China became the ASEAN's dialogue partner. At the end of the Cold War, the relationship between China and the NAM also entered a new era in which China was to become an observer in 1991, a status granted in 1992. For the NAM, the Chinese presence as the permanent member of the Security Council and the largest developing country in the world meant expanding the NAM's influence in international society. China growingly recognised multilateral diplomacy as a crucial means to secure state interests and shape international rules to create an enabling environment for development. In the 1990s, Beijing, therefore, joined various regional and international accords and increased the quality of its participation in multilateral organisations. Beijing's embrace of multilateral institutions represented one of the most dramatic shifts in its foreign relations. (Medeiros and Fravel, 2003) Beijing viewed participation of the NAM as a venue to increase its influence in international affairs. In October 1992, President Jiang Zemin declared "China is a developing country. Strengthening unity and cooperation with the third world is the cornerstone of China's foreign policy. China and the developing countries will continue to support each other in safeguarding independence and sovereignty and strengthening exchanges in economic and cultural aspects. China has become an observer of NAM and will reinforce cooperation with it in the future" (zhonggong zhongyang wenxian bianji weiyuanhui, 2006, pp. 243-244). The new circumstance changes in the post-Cold War rendered the utility and relevance of the NAM doubtful. Beijing rejected the redundancy and irrelevance of this movement and insisted that the NAM was still relevant. In the 1990s, China sent high-level delegations to attend a series of NAM summit meetings and reiterated its support to the relevance of the NAM in the postCold War period. At the 1992 NAM Summit Conference, Qian Qichen, China's Foreign Minister, speaking as an observer, emphasized that the NAM "will still play an important role in international affairs" (People's Daily, 1992). The issues China talked about in the NAM during this period encompassed from building a fair international political and economic order to promoting South-South cooperation and reinforcing multilateralism. In order to find and promote solutions to the problems that the NAM and China faced, apart from rhetorical support, a surge of cooperation between the NAM and China 
emerged in the 1990s. China and the Non-Aligned Coordination Bureau headquartered in New York had close consultations on current major international issues (Ding, 1994, p. 132). In 1999, China worked closely with the NAM under the UN structure in the fields of human rights, disarmament, and economics (zhonghua renmin gongheguo waijiaobu zhengce yanjiushi, 2000, p. 745).

\section{Gradually moving out China's attention (2000-2021)}

Despite China continued to express its support to the NAM, the $21^{\text {st }}$ century has been witnessing China's diminishing interests for the NAM. There are only 35 reports about the NAM in the People's Daily over the past twenty-one years. In contrast, 111 reports were published in the 1990s. In addition to shorter and shorter attention span, the level of the Chinese delegations to the NAM Summit Conferences gradually declined. Chinese delegations to the 13th, 14th and 15th NAM Summit Conferences were led by the Vice Foreign Minister from 2003 to 2009. In 2012, the Assistant Foreign Minister headed the Chinese delegation to participate in the 16th NAM Summit Conference. In 2016 and 2018, China's Special Representative for Latin America and Chinese Ambassador to Azerbaijan led a delegation to the 17th and 18th NAMSummit Conference, respectively. This partly stemmed from the NAM's lowered status and importance in Beijing's calculation of foreign relations, and partly resulted from the movement's inherent defects. As Chen argued, "The NAM has no headquarters or permanent body and its resolutions adopted by the summit Conferences lack binding force. The NAM is facing the test of continuous differentiation and reorganisation among developing countries. The current NAM needs to keep pace with the times, strengthening its competitiveness, and increase its voice in responding to the international financial crisis, climate change, food and energy crises and other global challenges." (People's Daily, 2009) In general, since the collapse of the Soviet Union, the NAM has been a movement adrift. Given its complex make-up, it is no surprise that the NAM faces increasing problems of coherence and cohesion. The NAM summits tend to be glorified gabfests. (Patrick, 2012)

\section{Conclusions}

In conclusion, China has always been sympathetic and supportive to the NAM and its main initiatives since its inception. During the Cold War, 
China and the NAM shared the progressive aspirations of anti-imperialism, anti-hegemonism, and the New International Economic Order. However, China had not joined the NAM before the end of the Cold War.

Beijing found it more useful to stay outside of the NAM because China was wary of such a forum as a venue that India and the Soviet Union would criticise and constrain itself. Thus, China selectively participated and supported the NAM initiatives, according to its national interests and ideology. In the post-Cold War era, China became an observer country to the NAM in 1992 and acted more proactively to woo the Third World countries. Overall, Beijing still adopts a modest attitude towards the NAM. China remains in observer status by now. Beijing attempts to leave policy space to address risks, rejecting the pursuit of narrow interests or specific ideology. The $21^{\text {st }}$ century witnesses that China attaches less importance to the NAM largely because the movement fails to grasp contemporary relevance.

\section{References}

Ding, Shizhong. (1994). Chinese Relationship with the Non-Aligned Movement, in D. S. Feng and X. Q. Tao (Ed.), in: Zhongguo nianjian (People's Republic of China Yearbook), (p. 132). Beijing: Zhongguo nianjianshe.

Dinkle, Jürgen. (2016). "Third world begins to flex its muscles": The NonAligned Movement and the North-South conflict during the 1970s, in: S. Bott, J. M. Hanhimaki, J. M. Schaufelbuehl and M. Wyss (Eds.), Neutrality and Neutralism in the Global Cold War: Between or within the blocs? (pp. 108-123). Oxon: Routledge.

Gao, Z. P, Cheng, J and Wei, C. C. (2018). China's Attitudes towards the Non-Aligned Movement and its Changes (1961-1991)-An Investigation based on "People's Daily", Decision with E Information, 9, pp. 10-20.

Goldstein, Avery. (2001). The Diplomatic Face of China's Grand Strategy: A Rising Power's Emerging Choice, No.168, China Quarterly, pp.835-864.

Lüthi, Lorenz, M. (2016 a). Non-Alignment, 1961-74, in: S. Bott, J. M. Hanhimaki, J. M. Schaufelbuehl and M. Wyss (Eds.), Neutrality and Neutralism in the Global Cold War: Between or within the blocs? (pp. 90-107). Oxon: Routledge.

Lüthi, Lorenz, M. (2016 b). The Non-Aligned Movement and the Cold War, 1961-1973, Journal of Cold War Studies, 18 (4), pp. 98-147. 
Niu, Jun. (2019). Lengzhan shidaide zhongguo zhanlüe juece (China's Strategic Decision in the Cold War Era). Beijing: Shijie zhishi chubanshe.

Medeiros, Evan S. and Taylor Fravel (2003, November 25). The Changing Face of Chinese Diplomacy, Asian Wall Street Journal.

Patrick, Stewart M. (2012, August 30). The Nonaligned Movement's Crisis. https:// www.cfr.org/blog/nonaligned-movements-crisis. Accessed 20 April 2021.

People's Daily. (1961a, September 1). Zhou zongli dianhe bujiemeng guojia huiyi (Premier Zhou sent a congratulatory message to Conference of Heads of State and Government of Non-Aligned Countries). People's Daily.

People's Daily. (1961b, September 4). Duoerdikesi, Enkeluma he sailaxiyishi zai bujiemeng guojia huiyishang jianghua qianglie qianze xinlao zhiminzhuyi he diguozhuyi (Dorticos, Nkrumah and Selassie I spoke at the Conference of Heads of State and Government of Non-Aligned Countries and strongly condemned old and neo colonialism and imperialism). People's Daily.

People's Daily. (1961c, September 10). Chenyi fuzongli tan bujiemeng guojiahuiyi fanyingle geguorenminde zhengyi husheng, meiyou duli he ziyou jiu tanbudao baowei heping, budasui diguozhuyi suolian jiu tanbudao gongchu (Vice Premier Chen Yi talked about the Conference of Heads of State and Government of Non-Aligned Countries which reflected the voice of the people of NAM countries. Without independence and freedom, there can be no talk of defending peace. Without breaking the chains of imperialism, there can be no talk of coexistence). People's Daily.

People's Daily. (1962a, December 10). Zhongguo zhengfu zhongxin yuzhu kelunpo bujiemeng guojia huiyi Chenggong Zhou Enlai zongli zhidian yuhuide geguo lingdaoren he daibiao (The Chinese Government wished the Colombo Non-Aligned Countries Conference a success. Premier Zhou Enlai called the leaders and representatives of the countries participating in the meeting). People's Daily.

People's Daily. (1962b, November 11). Yishou nameiyuan yishou nameiguo qiangpao changkuang fanhua nihelu bujiemeng huangzi zaiye pianbuliaoren (With U.S. dollars in one hand American guns in the other, the pretense of non-alignment of wild anti-China Nehru can no longer deceive people). People's Daily. 
People's Daily. (1962c, December 23). Yindu zhengfu suowei bujiemeng de zhengxiang (The Truth about the so-called non-alignment of the Indian Government). People's Daily.

People's Daily. (1964a, October 5). Zhou zongli dianhe dierci bujiemeng guojia huiyi (Premier Zhou sent a congratulatory message to the Second Conference of Heads of State and Government of Non-Aligned Countries). People's Daily.

People's Daily. (1964b, October 9). Xiasiteli zai kailuo changkuang fanhua junxinhezai jieli duhua bujiemeng guojia huiyi qifen dasi tiaobo zhongguo yu alian guanxi (What is Shastri's rampant intention of antiChina? He tried his best to poison the atmosphere of the meeting of nonaligned countries and to provoke China-UAE relations). People's Daily.

People's Daily. (1970, September 8). Zhou Enlai zongli zhidian zhuhe disanci bujiemeng guojia he zhengfu shounao huiyi (Premier Zhou sent a congratulatory message to celebrate the third Conference of Heads of State and Government of Non-Aligned Countries). People's Daily.

People's Daily. (1972, August 18). Geguo renmin de gongtong shengli-ji bujiemeng guojia waizhang huiyi relie huanying jianpuzhai wangguo minzu tuanjie zhengfu daibiaotuan (Common victory - a record of the Conference of Foreign Ministers of non-aligned countries warmly welcomed the delegations of the Royal Government of National Union of Cambodia)

People's Daily. (1973, September 5). Zhouzongli dianhe disici bujiemeng guojia he zhengfu shounao huiyi (Premier Zhou sent a congratulatory message to the fourth Conference of Heads of State and Government of Non-Aligned Countries). People's Daily.

People's Daily. (1979a, August 20). Bujiemeng guojia he zhengfu shounao huiyi jiekai xumu (The Conference of Heads of State and Government of Non-Aligned Countries kicked off). People's Daily.

People's Daily. (1979b, September 3). Huazongli dianhe diliuci bujiemeng guojia shounao huiyi zhongguo zhengfu jianjue zhichi bujiemeng guojiade zhengyi lichang he jijide xingdong (Premier Hua sent a congratulatory message to the Sixth Conference of Heads of State and Government of Non-Aligned Countries. The Chinese government firmly supported the fair stand and positive actions of the non-aligned countries). People's Daily.

People's Daily. (1983a, March 7). Diqici bujiemeng guojia he zhengfu shounao huiyi zhaokai Zhao Ziyang zongli zhidian reliezhuhe (The 
Seventh Conference of Heads of State and Government of Non-Aligned Countries was held. Premier Zhao Ziyang sent a congratulatory message to celebrate). People's Daily.

People's Daily. (1983b, July 30). Jiu dangqian guoji xingshi he shuangbian guanxi jiaohuan yijian Zhao zongli chanshu woguo chuli tong sumei guanxishi jianchide sanxiang yuanze (Premier Zhao held talks with President Da Costa. Premier Zhao elaborated on the three principles that China adhered to when handling relations with the Soviet Union and the United States). People's Daily.

People's Daily. (1989b, September 10). Tuidong bujiemeng yundong zai xinxingshixia fazhan (Promote the development of the Non-Aligned Movement under the new situation). People's Daily.

People's Daily. (1992, September 3). Qian Qichen zai dishici bujiemeng shounao huiyishang fabiao jianghua qiangdiao bujiemengde zhongyao zuoyong burong hushi (Qian Qichen delivered a speech at the Tenth Conference of Heads of State and Government of Non-Aligned Countries and emphasized that the important role of the Non-Aligned Movement cannot be ignored). People's Daily.

People's Daily. (2009, July 17). Guoji jinrong weiji tuxian fazhanzhongguojia gongtongliyi bujiemeng yundong jinru "shamushayihe shiduan" (The global financial crisis once again highlighted the common interests of developing countries. The Non-Aligned Movement entered the Sharm El-Sheikh period). People's Daily.

Stoecker, Sally W. (1989). Clients and Commitments: Soviet-Vietnamese Relations, 1978-1988, The Rand.

United Nations. (1973, November 22) Documents of the Fourth Conference of Heads of State or Government of Non-Aligned Countries, United Nations General Assembly, New York.

United Nations. (1979, October 11) Documents of the Sixth Conference of Heads of State or Government of Non-Aligned Countries, United Nations General Assembly, New York.

Wang, Xinqing. (1985, June 7). Zhengqu chijiu heping fazhan youhao hezuo cujin gongtong fanrong-Zhao Ziyang zongli zai yingguo huangjia guojia shiwusuo fabiaode yanjiang (Strive for lasting peace, develop friendly cooperation, and promote common prosperity. A speech delivered by Premier Zhao Ziyang at the Royal Institute of International affairs, UK). People's Daily. 
Wu, Lengxi. (1999). shinian lunzhan (A Decade of Debate) (Vol.1). Beijing, Zhongyang wenxuan chubanshe.

Xu Mingda. (2007). Ji huifu jianpuzhai zai bujiemeng yundongzhongde hefaxiwei (The Record of the restoration of Cambodia's legal seat in the Non-Aligned Movement), in Y. Zheng (Ed.), Waijiao jishi (Diplomatic Episodes) (Vol. 3). Beijing: Shijie zhishi chubanshe.

Yang, K.S. (2007). China's Reorientation during the Process of SinoAmerican Rapprochement: An Inquiry into the Background of Mao Zedong's Issuance of the "Three Worlds" Theory, Cold War International History Studies, 4, pp. 1-24.

Yan, Z and Xu B. (1989a, September 5). Dijiuci bujiemeng shounao huiyi kaimu huiyi zhuxi de'ernuofusheke fabiao zhuzhi jianghua (The Ninth Conference of Heads of State and Government of Non-Aligned Countries kicked off. The Chairman of the Conference Drnovsek delivered a keynote speech). People's Daily.

Zhang, Peisen, ed. (2000). Zhang Wentian nianpu, 1942-1976 (Chronological record of Zhang Wentian, 1942-1976) (Vol. 2). Beijing: Zhonggong dangshi chubanshe.

Zhonggong zhongyang wenxian yanjiushi, ed. (1994). Mao Zedong waijiao wenxuan (Diplomatic papers of Mao Zedong). Beijing: Zhongyang wenxian chubanshe.

Zhonggong zhongyang wenxian yanjiushi, ed. (1997). Zhou Enlai nianpu, 1949-1976 (Chronological record of Zhou Enlai, 1949-1976) (Vol. 3). Beijing: Zhongyang wenxian chubanshe.

Zhonggong zhongyang wenxian bianjishi weiyuanhui, ed. (1994). Deng Xiaoping wenxuan (Selected Works of Deng Xiaoping) (Vol. 2). Beijing: Renmin chubanshe.

Zhonggong zhongyang wenxian bianjishi weiyuanhui, ed. (1993). Deng Xiaoping wenxuan (Selected Works of Deng Xiaoping) (Vol. 3). Beijing: Renmin chubanshe.

Zhonggong zhongyang wenxian bianjishi weiyuanhui, ed. (2006). Jiang Zemin wenxuan (Selected Works of Jiang Zemin) (Vol. 1). Beijing: Renmin chubanshe.

Zhonghua renmin gongheguo waijiaobu zhengce yanjiushi, ed. (2000). Zhongguo waijiao (China's Foreign Affairs). Beijing: Shijie zhishi chubanshe. 